\title{
Skojarzenia słowne niewidomych i widzących użytkowników języka polskiego - studium porównawcze
}

\author{
Nawoja Mikołajczak-Matyja \\ Institute of Linguistics, Adam Mickiewicz University \\ ul. Międzychodzka 5, 60-371 Poznań \\ nawomiko@amu.edu.pl
}

\begin{abstract}
Verbal associations of blind and sighted users of the Polish language - a comparative study. The present paper concerns the role of visual perception in the cognitive (verbal and nonverbal) functioning of people. Verbal associations (free associations) given for 75 Polish nouns by 116 subjects ( 58 blind people and 58 sighted people) were analysed and compared.
\end{abstract}

\section{Wstęp: sposoby interpretowania wyników badań skojarzeniowych}

Przeprowadzane od ponad stu lat eksperymenty, polegające na podawaniu przez respondentów skojarzeń słownych na wyrazy jakiegoś języka naturalnego, znajdują zastosowanie w psychologii i językoznawstwie, a od kilkudziesięciu lat także w psycholingwistyce (przegląd badań skojarzeniowych por. m.in. Hörmann 1972, Ciechanowicz 1975, Kurcz 1976). Związek eksperymentu skojarzeniowego z takimi dziedzinami wiedzy wynika z możliwości interpretowania jego wyników zarówno w terminach zachowania językowego osób badanych, jak i w terminach procesów myślenia, uczenia się i pamięci oraz procesów emocjonalno-motywacyjnych. Pojęcie asocjacji, które współczesna nauka przejęła głównie z prac Arystotelesa ${ }^{1}$, można rozumieć jako dotyczące idei, obrazów i myśli (Hörmann 1972). Ujmowanie skojarzenia jako związku takich zjawisk świadomości stało się podstawą psychologii introspekcyjnej, pierwszego nurtu psychologii jako dziedziny wyodrębnionej z filozofii (Tomaszewski 1986).

Za prekursora eksperymentu skojarzeniowego o charakterze werbalnym uważa się Galtona (Deese 1965, Hörmann 1972, Ciechanowicz 1975, Kurcz 1976, 2000). Bodźcami w jego badaniu były bowiem wyrazy, a podane przez siebie samego reakcje Galton podzielił na różne grupy, m.in. na reprezentacje wizualne zdarzeń przeszłych, skojarzenia dotyczące postaw i skojarzenia „czysto werbalne” (Deese 1965, Hörmann 1972). „Anatomia umysłu” odsłaniana w badaniach tego typu stanowi punkt styczności między takimi gałęziami psychologii, jak psychoanaliza, psychologia uczenia się i psycholingwistyka (Hörmann 1972).

Współczesne badania nad skojarzeniami słownymi można podzielić na grupowe, których celem jest ustanawianie norm skojarzeniowych dla danego języka lub/i porównywanie reakcji 2 grup zróżnicowanych wg jakiegoś kryterium (jak np. wiek, płeć, wykształcenie, język itp.), oraz badania indywidualne, w których porównuje się odpowiedzi udzielane przez danego respondenta z normami uzyskanymi w badaniach grupowych. W badaniach grupowych stosuje się interpretacje językowe $\mathrm{i}$

\footnotetext{
${ }^{1}$ Warren wyprowadza ideę skojarzenia z pewnego cytatu Platona (Warren 1916, za: Deese 1965).
} 
pozajęzykowe. Na przykład punktem wyjścia analizy różnic między normami skojarzeniowymi uzyskiwanymi dla różnych języków naturalnych może być próba określenia stopnia zależności tych różnic od cech porównywanych języków lub od procesów pozajęzykowych (por. np. badania porównawcze dotyczące języka polskiego i angielskiego, Shugar, Gepner-Więcko 1970, Kurcz 1976). Natomiast eksperymenty indywidualne przeprowadzane są głównie w celu diagnozowaniu zaburzeń o podłożu emocjonalnym, zmian osobowościowych, zaburzeń psychotycznych itp.

Jest przedmiotem dyskusji, na ile podawanie przez badanego skojarzeń nietypowych, tj. niezgodnych z normami, można uważać za znaczące z punktu widzenia procesów pozajęzykowych. Pojawiła się np. teoria podająca w wątpliwość wartość psychoanalitycznych badań Junga, interpretującego określone sposoby reagowania w badaniu skojarzeniowym jako wskaźniki kompleksów występujących u osoby badanej (Laffal 1955, za: Hörmann 1972). Relacje między sposobem reagowania $\mathrm{w}$ eksperymencie skojarzeniowym a cechami pozajęzykowymi analizowano $\mathrm{w}$ bloku badań opisywanych przez Jenkinsa (1960). Badania te nie wykazały wyraźnego związku między tzw. stopniem powszechności skojarzeń (czyli stopniem zgodności reakcji danego badanego $\mathrm{z}$ odpowiedziami typowymi, dominującymi w danej grupie respondentów) a stopniem konformizmu, wynikami testu osobowości MMPI, testu zainteresowań itp. Stopień powszechności skojarzeń odpowiada raczej określonym ilościowym i jakościowym cechom dostępnych powiązań między wyrazami (Jenkins 1960), a więc cechom budowy leksykonu umysłowego.

Jednakże istnieją teorie pozwalające na analizowanie związku między skojarzeniami słownymi a procesami emocjonalno-motywacyjnymi, np. teoria Hulla, uzupełniona przez Mednicka (za: HuncaBednarska 1997). Pojawiła się także teoria łącząca oba sposoby analizowania skojarzeń werbalnych: jako wskaźnika procesów pozawerbalnych i jako cechy zachowania językowego. Jest to teoria Rommetveita, która rozpatruje 3 aspekty procesu przetwarzania wyrazu uruchamianego podczas eksperymentu skojarzeniowego: aspekt reprezentacyjny (stanowiący konsekwencję odniesienia do pojęcia kryjącego się pod wyrazem bodźcowym), emocjonalny i asocjacyjny (Rommetveit 1968).

Trudności w sprecyzowaniu sposobu i stopnia odzwierciedlenia różnych procesów psychicznych w wynikach testów skojarzeniowych można traktować jako efekt złożoności relacji między językiem a myśleniem i rzeczywistością. Rolę takich eksperymentów we współczesnej nauce potwierdzają badania prowadzone na przestrzeni ostatnich kilkunastu lat. Ciagle opracowywane są nowe normy skojarzeniowe, np. dla języków: francuskiego (Ferrand, Alario 1998, Ferrand 2001), angielskiego (Hirsh, Tree 2001), polskiego (Łobacz, Mikołajczak-Matyja 2002) itd. Zgodnie z założeniami badaczy opracowujących normy, mają one być wykorzystywane w zarówno w badaniach z zakresu psycholingwistyki, jak i psychologii pamiecci oraz psychopatologii.

$\mathrm{W}$ ostatnich dekadach eksperymenty i normy skojarzeniowe są intensywnie wykorzystywane do uzyskania wiedzy na temat procesu produkcji i odbioru mowy oraz roli leksykonu umysłowego $\mathrm{w}$ tym procesie. Relacje uzyskane w badaniach skojarzeniowych pomagają w rekonstruowaniu procesu produkcji zdania, w wyciąganiu wniosków dotyczących funkcjonowania leksykonu umysłowego, dostępu do leksykonu i jego struktury (por. np. Moss, Ostrin, Tyler, Marslen-Wilson 1995, Bock 2002, Forster 2002). Eksperymenty i normy skojarzeniowe wykorzystuje się także do badań nad akwizycją języka drugiego (L2): do ustalania struktury leksykonu w L2 w porównaniu z leksykonem w L1 (por. Cieślicka-Ratajczak 1995, Wilks, Meara 2002) i do oceny sprawności posługiwania się L2 (Wolter 2002). Do psycholingwistycznych obszarów wykorzystywania skojarzeń werbalnych zaliczyć też można badania nad procesem czytania (Cronin 2002) oraz nad osobami z zaburzeniami mowy (Crowe, Kroll 1991). Eksperyment skojarzeniowy o charakterze werbalnym łączy się z psychologicznymi badaniami nad pamięcią (Latour, McKelvie 1994) i nad rozwojem poznawczym u dzieci (Houde 1990). Kontynuowana jest również tradycja wykorzystywania danych skojarzeniowych w psychologii osobowości i w psychopatologii, np. do badań nad cechami neurotyzmu, ekstrawersji, psychotyzmu, kreatywności itp. (Upmanyu, Bhardwaj, Singh 1996) lub nad schizofrenią (Johnson, Shean 1993, Hunca-Bednarska 1997).

Analiza reakcji uzyskanych od schizofreników w ostatniej $\mathrm{z}$ wymienionych prac ukazuje możliwość łączenia różnych interpretacji wyników badania skojarzeniowego: od „,powierzchniowej” 
budowy leksykonu umysłowego, poprzez cechy myślenia i procesów emocjonalnych aż po głębokie procesy osobowościowe, takie jak postrzeganie siebie (Hunca-Bednarska 1997).

We współczesnych pracach psycholingwistycznych poruszany jest problem, który wydaje się być w jakimś stopniu związany z pytaniem o możliwość i zasięg wykorzystywania skojarzeń słownych jako wskaźników procesów pozawerbalnych. Chodzi tu mianowicie o problem powiązania pomiędzy siłą związku skojarzeniowego bodziec-reakcja a relacją semantyczną wiążącą te dwa wyrazy. Tradycja analizowania wyników eksperymentu skojarzeniowego poprzez określanie relacji semantycznej między bodźcem a reakcją jest bardzo długa: na wyróżnieniu asocjacji typu częśćcałość, nadrzędność-podrzędność, współrzędność, przeciwieństwo opierała się już klasyfikacja Wundta (Wundt 1893, za: Hörmann 1972). Klasyfikację tę krytykowano jako nadmiernie związaną z zasadami logiki formalnej (Thumb, Marbe 1901, za: Hörmann 1972), ale konieczność określania relacji semantycznych wynika również ze znanych klasyfikacji późniejszych, np. Woodwortha (znajdujemy w niej m.in. klasy: synonimy i pojęcia nadrzędne, pojęcia współrzędne i przeciwieństwa, za: Hörmann 1972, Kurcz 1976) czy Flavella (Flavell wymienił synonimy oraz reakcje nadrzędne wśród skojarzeń tzw. dojrzałych, a reakcje kontrastowe wśród skojarzeń pośrednich między dojrzałymi a niedojrzałymi, za: Hunca-Bednarska 1997). We wspomnianej wyżej teorii Rommetveita reakcje nadrzędne, synonimy, przeciwieństwa i reakcje współrzędne (kohiponimy) uważane są za odzwierciedlenie składnika reprezentacyjnego procesu skojarzeniowego (Rommetveit 1968). Jak dowodzą analizy Huncy-Bednarskiej, określanie relacji semantycznych może stać się podstawą wniosków dotyczących procesów myślenia osób podających skojarzenia (Hunca-Bednarska 1997).

Skojarzenia połączone z bodźcem ścisłymi relacjami semantycznymi (takimi jak synonimia, relacja część-całość, hiponimia czy antonimia) dość często uzyskują status skojarzeń typowych czy nawet najsilniejszych (por. np. analiza semantyczna polskich skojarzeń dominujących $\mathrm{w}$ pracy Łobacz, Mikołajczak-Matyja 2002). Jednakże obecnie w badaniach analizujących rolę składnika semantycznego w procesach przetwarzania mowy często wyraźnie oddziela się relacje semantyczne od skojarzeniowych, np. w badaniach wykorzystujących technikę torowania ${ }^{2}$ stosuje się oprócz par wyrazów połączonych semantycznie i skojarzeniowo (tzn. jeden wyraz z pary stanowi silną, typową reakcję na drugi wyraz), także pary połączone tylko semantycznie, przy czym relacje semantyczne wykorzystywane w przypadku obu rodzajów par mogą być takie same, np. odpowiednio srebrnyzłoty i srebrny-brazowy (por. np. Moss, McCormick, Tyler 2002). Odmienność wyników uzyskiwana dla takich par doprowadziła do rozróżniania torowania asocjacyjnego (niezależnego od powiązań semantycznych) i torowania semantycznego nieasocjacyjnego, które dotyczą różnych aspektów procesu przetwarzania mowy (Harley 2003). Torowanie oparte na silnych związkach skojarzeniowych między wyrazami określa się niekiedy jako „czysto werbalne” (Simpson 2002). Uważa się bowiem, iż podstawą skojarzeń jest częste współwystępowanie wyrazów w języku, podczas gdy relacje semantyczne między wyrazami opierają się na podobieństwie kontekstów, w których występują (na możliwości wzajemnego ich podstawiania w tych kontekstach) i na związkach „wyższego rzędu" (Moss, McCormick, Tyler 2002, Harley 2003). Dowody (pochodzące z badań skojarzeniowych), że podobieństwo znaczeniowe dwóch wyrazów nie zawsze prowadzi do silnego związku skojarzeniowego i oparte na tych dowodach przekonanie o odmiennym pochodzeniu relacji skojarzeniowych i semantycznych, znacznie ograniczają użyteczność tzw. asocjacyjnych teorii znaczenia, ujmujących znaczenie wyrazu w terminach skojarzeń werbalnych. Zgodnie z tymi teoriami pokrewieństwo dwóch wyrazów wyznaczone jest przez częstość łączenia ich (jako bodźca i reakcji) w badaniu skojarzeniowym albo przez liczbę reakcji skojarzeniowych wspólnych na te dwa wyrazy jako bodźce (Deese 1965, Hörmann 1972).

Złożoność związków między skojarzeniem a semantyką prowadzi do wniosku, że silne (typowe) reakcje skojarzeniowe połączone $\mathrm{z}$ bodźcem ścisłą relacją semantyczną można interpretować zarówno $\mathrm{w}$ terminach zachowania werbalnego (współwystępowania bodźca i reakcji w

\footnotetext{
${ }^{2} \mathrm{~W}$ technice torowania (ang. priming) wcześniejsze przetwarzanie jednego wyrazu (tzw. wyrazu torującego) wpływa na przetwarzanie innego wyrazu, jeśli istnieje między nimi jakiś rodzaj związku (por. np. Kurcz 2002, Harley 2003).
} 
wypowiedziach), jak i w terminach zachowań pozawerbalnych (wpływających na relacje „,wyższego rzędu”, czyli semantyczne), być może z większym naciskiem na pierwszy rodzaj interpretacji.

Podwójnej interpretacji - językowej i pozajęzykowej - można poddawać także skojarzenia wytwarzane przez specyficzną grupę respondentów, jaką stanowią osoby niewidome. Defekt podstawowego narządu zmysłu, zmieniający w ogromnym stopniu sposób poznawania świata, wyznacza specyfikę rozwoju zarówno procesów emocjonalno-społecznych i poznawczych (por. np. Pietrulewicz 1981, 1983, Majewski 1983, Niesiołowska 1985, Klimasiński 1989, Warren 1994), jak i, w pewnym stopniu, procesów językowych. Odmienność funkcjonowania osób niewidomych i widzących dotyczy m.in. tego aspektu procesów językowych, z którym bezpośrednio wiążą się badania skojarzeniowe, tj. z aspektem leksykalnym. Zwraca się uwagę na szczególnie dużą rolę werbalnego wyjaśniania znaczeń wyrazów w nabywaniu słownictwa przez dzieci niewidome, wyjaśniania kompensującego brak spostrzegania wzrokowego, które odgrywa dużą rolę w tym procesie u osób widzących (Elbers, Van Loon-Vervoorn 1999). W różnych badaniach stwierdzono pewne charakterystyczne cechy rozwoju znaczenia wyrazów u dzieci niewidomych, jak np. silniejszy związek wyrazów używanych przez dzieci niewidome $\mathrm{z}$ ich pierwotnym kontekstem i dłuższe używanie wyrazów odnoszących się do czynności w odniesieniu jedynie do własnych działań (Andersen i inni, 1984, 1993, Dunlea 1984, 1989, za: Warren 1994, Pérez-Pereira, Conti-Ramsden 1999). Zjawiska takie można interpretować w terminach wpływu dostępu do informacji na sposób zachowania językowego (Warren 1994, Pérez-Pereira, Conti-Ramsden 1999). Przedmiotem zainteresowania jest także sposób posługiwania się przez osoby niewidome wyrazami o treści wizualnej i przestrzennej, które wiąże się ze zjawiskiem tzw. werbalizmu (posługiwania się słowami „pustymi znaczeniowo”). Z badań wynika, że dzieci niewidome, zwłaszcza starsze, rzadko stosują takie wyrazy bez zrozumienia, chociaż przekazywane w nich znaczenie bazuje na pojęciach o innej strukturze, niż u osób widzących (por. np. Harley 1963 za: Klimasiński 1989, Tutenkijan 1971 za: Warren 1994, Sẹkowska 1974). Prowadzi się również badania porównawcze z użyciem metody skojarzeniowej, w których wykorzystuje się możliwość stosowania analiz wyników do wnioskowania o różnych procesach psychicznych osób badanych. W polskich badaniach przeprowadzonych przez Szczechowicz na grupie 30 dzieci niewidomych (z klas III-VIII) i kontrolnej grupie dzieci widzących stwierdzono w wynikach osób niewidomych mniejszą zgodność kategorii gramatycznej między bodźcem a reakcją oraz silniejszą tendencję do podawania odpowiedzi klasyfikowanych jako abstrakcyjne, powiązanych z przeżyciami emocjonalnymi. Wyniki te posłużyły (wraz z rezultatami innych eksperymentów) do wyciagania wniosków dotyczących rozwoju pojęć u osób niewidomych i widzących (por. Szczechowicz 1976).

\section{Cel i metoda badań, materiał badawczy i respondenci}

Celem badań prezentowanych $\mathrm{w}$ obecnej pracy jest ukazanie roli spostrzegania wzrokowego w funkcjonowaniu poznawczym człowieka poprzez szczegółową analizę porównawczą skojarzeń słownych podanych przez niewidomych i widzących użytkowników jezzka polskiego, $\mathrm{z}$ wykorzystaniem specjalnie opracowanego materiału werbalnego, zróżnicowanego pod względem związku z informacjami wzrokowymi.

Przeprowadzono test skojarzeniowy o charakterze prostym i swobodnym, tj. proszono respondentów o podanie pierwszego wyrazu kojarzącego się z bodźcem - wyrazem hasłowym.

Dla potrzeb eksperymentu skonstruowano listę haseł składającą się z 75 polskich rzeczowników, o których można założyć, że są znane naiwnym użytkownikom języka polskiego. Starano się, aby zastosowany materiał był jednocześnie różnorodny i uporządkowany. Wybrano zatem rzeczowniki należące do 25 3-elementowych grup, które można traktować jako reprezentujące odrębne pola leksykalne. Realność takiej klasyfikacji została potwierdzona w dodatkowo przeprowadzonym badaniu, w którym 45 studentów filologii nadawało hasłom z każdej 3-elementowej grupy wspólną nazwę. Określenia podane przez tych respondentów stosowane są w obecnej pracy jako nazwy 25 grup, zwanych dalej klasami semantycznymi. Są to następujące klasy: 
1. Drzewa: sosna, buk, brzoza

2. Owoce i warzywa: cytryna, pomidor, marchew

3. Zwierzęta: gil, lis, osa

4. Części ciała: ręka, tapa, oko

5. Ludzie: nauczyciel, egoista, biedak

6. Grupy ludzi: gang, brygada, drużyna

7. Płyny organizmu: ślina, pot, krew

8. Pożywienie: piwo, kietbasa, ser

9. Urządzenia: komputer, telefon, pralka

10. Pojazdy: traktor, autobus, ciężarówka

11. Kosmetyki: mydto, szampon, dezodorant

12. Budynki: chata, kamienica, pałac

13. Części domu: komin, dach, okno

14. Elementy pomieszczenia: ściana, podtoga, sufit

15. Miejsca handlowo-usługowe: apteka, kawiarnia, księgarnia

16. Tereny: boisko, tqka, podwórze

17. Elementy krajobrazu: wzgórze, jaskinia, rzeka

18. Zjawiska atmosferyczne: tęcza, błyskawica, grad

19. Materiały: metal, szkto, beton

20. Dzieła sztuki: symfonia, powieść, posag

21. Czas: wtorek, marzec, jesień

22. Dźwięki: wrzask, gwizd, tupot

23. Czynności: morderstwo, walka, krok

24. Emocje: radość, zdziwienie, strach

25. Cechy charakteru: lekkomyślność, uczciwość, ostrożność

Jak widać, klasy są niejednakowo zróżnicowane wewnętrznie i niektóre z nich można łączyé w większe pola leksykalne (np. Drzewa + Owoce i Warzywa $=$,Rośliny” + Zwierzęta $=$ „Istoty Żywe").

$\mathrm{Z}$ uwagi na cel badania starano się także dobrać hasła różnorodne pod względem roli wzroku w poznaniu ich desygnatów przez osoby widzące (roli informacji wzrokowych w konstruowaniu przez widzących pojęć odpowiadających tym hasłom). Wybierając rzeczowniki zróżnicowane pod tym względem brano pod uwagę takie cechy, jak np. kolor, przezroczystość i połysk desygnatów, ich wielkość (od której zależy dokładność dotykowego poznawania kształtów), dostępność (odległość, wysokość, rodzaj środowiska), postać fizyczna (gazowa, płynna lub stała o różnym stopniu twardości), możliwość jednoczesnej percepcji wzrokowej przedmiotu w porównaniu $\mathrm{z}$ sekwencyjnością poznania dotykowego. W materiale badawczym znalazły się zatem z jednej strony nazwy zjawisk całkowicie wzrokowych, jak tęcza czy błyskawica, z drugiej - rzeczowniki słabo związane z danymi wzrokowymi, jak nazwy cech i funkcji osób (lekkomyślność, uczciwość, ostrożność, egoista, nauczyciel, biedak) oraz przedziały czasowe (wtorek, marzec), wreszcie rzeczowniki, które można umiejscowić między tymi skrajnościami, a więc np. desygnujące obiekty barwne (np. pomidor), trudno dostępne (np. dach), małe (np. osa), płynne (np. pot), bardzo duże (np. pałac) itp.

Materiał został uporządkowany losowo.

Przebadano 116 osób: 58 niewidomych i 58 widzących uczniów klas: I - III gimnazjum, II - IV liceum ogólnokształcącego oraz II - IV szkół średnich zawodowych ${ }^{3}$. Badaniu poddano osoby całkowicie niewidome lub jedynie z poczuciem światła, bez zachowanych wspomnień wzrokowych (z dysfunkcją wzroku ujawnioną od urodzenia lub we wczesnych latach życia). Dodatkowe kryteria doboru 58-osobowej grupy kontrolnej osób widzących stanowiły: płeć oraz wyniki w nauce określane na skali: słaby, średni, dobry i bardzo dobry. Badania przeprowadzano w 5 Ośrodkach Szkolno-Wychowawczych dla Dzieci i Młodzieży Niewidomej i Słabowidzącej (w Owińskach k/Poznania, Krakowie, Bydgoszczy, Laskach k/Warszawy oraz Wrocławiu) oraz w szkołach

\footnotetext{
${ }^{3}$ Na skutek reformy szkolnictwa w momencie przeprowadzania badań nie było poziomu klas I średnich w szkolnictwie masowym. 2 uczniów niewidomych z klas I liceum ogólnokształcącego i zawodowego (klas stanowiących wyjątkowe uzupełnienie szkolnictwa osób niewidomych po reformie) potraktowano jako osoby z poziomu III klasy gimnazjum, ze względu na brak odpowiedników w zreformowanym szkolnictwie osób widzących.
} 
ponadpodstawowych w Poznaniu. Większość badań przeprowadzono w roku szkolnym 2001/2002, pozostałe w roku 2002/2003.

Test miał charakter pisemny. Instrukcje i listy haseł dla osób niewidomych zostały wydrukowane alfabetem Braille'a (w wersji sześciopunktowej) przy użyciu drukarki Mountbatten Brailler. Do udzielania odpowiedzi respondenci z tej grupy używali (z jednym wyjątkiem) maszyn brajlowskich. Ze względu na specyfikę grupy eksperymentalnej zastosowano technikę polegającą na przepisywaniu przez osobę badaną hasła i wpisywaniu za nim odpowiedzi. Technikę tę zastosowano dla obu grup, w celu ujednolicenia sytuacji badawczej.

\section{Analiza wyników}

Uzyskano 4325 reakcji skojarzeniowych od osób niewidomych i 4291 od osób widzących. Analiza wyników polegała na:

1. porównaniu powszechności skojarzeń w obu grupach,

2. porównaniu skojarzeń dominujących $\mathrm{w}$ obu badanych grupach pod względem: proporcji reakcji wspólnych i odmiennych w obu grupach, siły skojarzeń (czyli liczby osób dających reakcje dominujące), zgodności kategorii gramatycznej między bodźcem a reakcją oraz relacji semantycznych między bodźcem a reakcją,

3. ogólnym treściowym porównaniu całego uzyskanego materiału.

\subsection{Powszechność skojarzeń}

Powszechność skojarzeń, czyli wewnętrzną spójność reakcji w obu badanych grupach porównano, obliczając dla każdej z nich średnią liczbę różnych reakcji na hasło (jest to jeden ze stosowanych wskaźników powszechności skojarzeń, por. np. Shugar, Gepner-Więcko 1970, Kurcz 1976). Średnia uzyskana dla grupy osób widzących $(28,4)$ okazała się nieco wyższa, niż w grupie respondentów niewidomych $(25,8)$, mimo ogólnie mniejszej liczby skojarzeń uzyskanej od grupy widzących (por. wyżej ogólną liczbę reakcji). Różnica między średnimi, mierzona testem t, okazała się istotna na poziomie $\alpha=0,01$. Powszechność reakcji zbadano także przy pomocy wskaźnika siły reakcji dominujących (por. niżej).

\subsection{Skojarzenia dominujące}

Dla każdego hasła z listy wyodrębniono reakcje dominujące, tj. podane przez największą liczbę osób $\mathrm{z}$ danej grupy. Za identyczne uznawano jedynie odpowiedzi w liczbie pojedynczej i mnogiej oraz równoznaczne formy „lek”(i) / „lekarstwo”(a). Traktowanie jako oddzielnych wszystkich innych typów reakcji (np. rzeczowników i przymiotników o tym samym rdzeniu, form podstawowych i deminutywnych rzeczowników czy nawet różnych przypadków gramatycznych reakcji rzeczownikowych) pozwala $\mathrm{z}$ jednej strony na stwierdzenie stopnia rzeczywistej identyczności reakcji badanych grup osób, a z drugiej - na dokładną ocenę relacji między bodźcem a reakcją. Dla kilku haseł otrzymano więcej niż jedną reakcję dominującą w danej grupie. Reakcje dominujące uzyskane od niewidomych i widzących zawiera tabela. Wytłuszczoną czcionką wyodrębniono reakcje odmienne dla obu grup. 
Tabela: Skojarzenia dominujace

\begin{tabular}{|c|c|c|c|c|}
\hline \multirow{2}{*}{ hasło } & \multicolumn{2}{|c|}{ Niewidomi } & \multicolumn{2}{|c|}{ Widzący } \\
\hline & reakcje & $\begin{array}{c}\text { procent } \\
\text { osób }\end{array}$ & reakcje & $\begin{array}{c}\text { procent } \\
\text { osób }\end{array}$ \\
\hline sosna & drzewo; igła (y) & 24,1 & drzewo & 31,0 \\
\hline buk & drzewo & 67,2 & drzewo & 50,0 \\
\hline brzoza & drzewo & 75,9 & drzewo & 63,8 \\
\hline gil & ptak & 70,7 & ptak & 60,3 \\
\hline lis & zwierzę & 37,9 & zwierzę; chytrość & 13,8 \\
\hline osa & owad & 46,6 & żądło & 29,3 \\
\hline cytryna & owoc & 25,9 & kwas & 24,1 \\
\hline pomidor & warzywo & 32,8 & warzywo (a) & 20,7 \\
\hline marchew & warzywo & 60,3 & warzywo & 27,6 \\
\hline wtorek & dzień & 51,7 & dzień tygodnia & 24,1 \\
\hline marzec & miesiac & 55,2 & miesiac & 24,1 \\
\hline jesień & deszcz & 19,0 & $\begin{array}{l}\text { miesiąc } \\
\text { liście }\end{array}$ & 27,6 \\
\hline komputer & internet & 20,7 & gra (y) & 29,3 \\
\hline telefon & rozmowa & 34,5 & rozmowa $(\mathrm{y})$ & 37,9 \\
\hline pralka & pranie & 41,4 & pranie & 20,7 \\
\hline ręka & dłoń & 20,7 & dłoń & 20,7 \\
\hline tapa & pies & 25,9 & pies & 51,7 \\
\hline oko & wzrok & 34,5 & wzrok & 13,8 \\
\hline chata & dom & 25,9 & wieś; dom & 20,7 \\
\hline kamienica & dom & 24,1 & dom & 19,0 \\
\hline patac & król & 22,4 & król; zamek & 12,1 \\
\hline piwo & alkohol & 32,8 & alkohol & 17,2 \\
\hline kietbasa & jedzenie & 34,5 & mięso; jedzenie & 17,2 \\
\hline ser & jedzenie & 13,8 & mysz & 24,1 \\
\hline apteka & lekarstwo(a, leki) & 70,7 & lekarstwo (lek, a, i) & 60,3 \\
\hline kawiarnia & kawa & 25,9 & kawa & 24,1 \\
\hline księgarnia & książka (i) & 65,5 & książka (i) & 74,1 \\
\hline ślina & wydzielina; plucie & 8,6 & język & 17,2 \\
\hline pot & zmęczenie & 19,0 & smród & 25,9 \\
\hline krew & $\begin{array}{l}\text { zmęczenie } \\
\text { rana }\end{array}$ & 15,5 & rana & 12,1 \\
\hline traktor & pole & 15,5 & pole & 24,1 \\
\hline autobus & pojazd & 22,4 & bilet (y) & 8,6 \\
\hline ciężarówka & samochód & 50,0 & samochód & 32,8 \\
\hline gang & mafia & 31,0 & mafia & 15,5 \\
\hline brygada & wojsko & 15,5 & wojsko & 12,1 \\
\hline drużyna & sport & 12,1 & zespół & 15,5 \\
\hline nauczyciel & szkoła & 29,3 & szkoła & 22,4 \\
\hline egoista & samolub & 34,5 & samolub & 25,9 \\
\hline biedak & żebrak & 29,3 & żebrak & 24,1 \\
\hline mydto & czystość & 17,2 & czystość & 25,9 \\
\hline szampon & włosy & 53,4 & włosy & 50,0 \\
\hline dezodorant & zapach & 44,8 & zapach & 31,0 \\
\hline symfonia & muzyka & 32,8 & muzyka & 31,0 \\
\hline powieść & książka & 37,9 & książka & 32,8 \\
\hline posag & rzeźba & 29,3 & rzeźba & 13,8 \\
\hline
\end{tabular}




\begin{tabular}{|c|c|c|c|c|}
\hline $\begin{array}{l}\text { metal } \\
\text { szkto } \\
\text { beton }\end{array}$ & \begin{tabular}{|l|} 
muzyka \\
szklanka (i) \\
budowa; chodnik
\end{tabular} & $\begin{array}{l}10,3 \\
19,0 \\
12,1\end{array}$ & $\begin{array}{l}\text { muzyka } \\
\text { szyba }(y) \\
\text { twardy }\end{array}$ & $\begin{array}{l}10,3 \\
22,4 \\
10,3\end{array}$ \\
\hline $\begin{array}{l}\text { radość } \\
\text { zdziwienie } \\
\text { strach }\end{array}$ & \begin{tabular}{|l} 
szczęście \\
zaskoczenie \\
lęk
\end{tabular} & $\begin{array}{l}25,9 \\
31,0 \\
27,6\end{array}$ & \begin{tabular}{|l|} 
szczęście \\
zaskoczenie \\
lęk
\end{tabular} & $\begin{array}{l}27,6 \\
29,3 \\
12,1\end{array}$ \\
\hline $\begin{array}{l}\text { boisko } \\
\text { takka } \\
\text { podwórze }\end{array}$ & $\begin{array}{l}\text { piłka } \\
\text { trawa } \\
\text { zabawa }(y) \\
\end{array}$ & $\begin{array}{l}39,7 \\
29,3 \\
12,1\end{array}$ & $\begin{array}{l}\text { piłka } \\
\text { kwiaty } \\
\text { zabawa (y) }\end{array}$ & $\begin{array}{l}17,2 \\
22,4 \\
17,2\end{array}$ \\
\hline $\begin{array}{l}\text { morderstwo } \\
\text { walka } \\
\text { krok }\end{array}$ & $\begin{array}{l}\text { zbrodnia } \\
\text { bitwa; wojna (y) } \\
\text { chodzenie }\end{array}$ & $\begin{array}{l}13,8 \\
17,2 \\
15,5 \\
\end{array}$ & $\begin{array}{l}\text { zbrodnia } \\
\text { wojna; bitwa } \\
\text { noga (i) } \\
\end{array}$ & $\begin{array}{l}10,3 \\
12,1 \\
13,8 \\
\end{array}$ \\
\hline $\begin{array}{l}\text { wrzask } \\
\text { gwizd } \\
\text { tupot }\end{array}$ & $\begin{array}{l}\text { krzyk } \\
\text { dźwięk } \\
\text { hałas }\end{array}$ & $\begin{array}{l}39,7 \\
19,0 \\
25,9 \\
\end{array}$ & $\begin{array}{l}\text { krzyk } \\
\text { hałas } \\
\text { hałas }\end{array}$ & $\begin{array}{l}29,3 \\
15,5 \\
34,5 \\
\end{array}$ \\
\hline $\begin{array}{l}\text { komin } \\
\text { dach } \\
\text { okno } \\
\end{array}$ & $\begin{array}{l}\text { dym } \\
\text { dom } \\
\text { widok; szyba } \\
\end{array}$ & $\begin{array}{l}44,8 \\
25,9 \\
19,0 \\
\end{array}$ & \begin{tabular}{|l} 
dym \\
dachówka (i) \\
szyba
\end{tabular} & $\begin{array}{l}48,3 \\
25,9 \\
17,2 \\
\end{array}$ \\
\hline $\begin{array}{l}\text { tęcza } \\
\text { btyskawica } \\
\text { grad }\end{array}$ & $\begin{array}{l}\text { kolory } \\
\text { burza } \\
\text { deszcz; lód }\end{array}$ & $\begin{array}{l}19,0 \\
41,4 \\
13,8 \\
\end{array}$ & $\begin{array}{l}\text { kolory } \\
\text { burza } \\
\text { śnieg } \\
\end{array}$ & $\begin{array}{l}36,2 \\
34,5 \\
19,0 \\
\end{array}$ \\
\hline $\begin{array}{l}\text { wzgórze } \\
\text { jaskinia } \\
\text { rzeka }\end{array}$ & $\begin{array}{l}\text { góra }(y) \\
\text { ciemność } \\
\text { woda }\end{array}$ & $\begin{array}{l}31,0 \\
15,5 \\
37,9\end{array}$ & $\begin{array}{l}\text { góra }(\mathrm{y}) \\
\text { ciemność; niedźwiedź } \\
\text { woda }\end{array}$ & $\begin{array}{l}22,4 \\
13,8 \\
39,7\end{array}$ \\
\hline $\begin{array}{l}\text { ściana } \\
\text { podtoga } \\
\text { sufit }\end{array}$ & $\begin{array}{l}\text { mur } \\
\text { dywan } \\
\text { strop, dach; dom }\end{array}$ & $\begin{array}{l}36,2 \\
13,8 \\
12,1\end{array}$ & $\begin{array}{l}\text { tapeta }(\mathbf{y}) \\
\text { dywan } \\
\text { lampa }(\mathbf{y})\end{array}$ & $\begin{array}{l}12,1 \\
25,9 \\
13,8\end{array}$ \\
\hline $\begin{array}{l}\text { lekkomyślność } \\
\text { uczciwość } \\
\text { ostrożność }\end{array}$ & $\begin{array}{l}\text { głupota } \\
\text { dobroć } \\
\text { uwaga }\end{array}$ & $\begin{array}{l}24,1 \\
13,8 \\
27,6 \\
\end{array}$ & \begin{tabular}{|l|} 
głupota \\
szczerość \\
rozwaga \\
\end{tabular} & $\begin{array}{l}25,9 \\
10,3 \\
12,1 \\
\end{array}$ \\
\hline
\end{tabular}

Proporcja reakcji wspólnych: Przynajmniej 1 reakcję dominującą wspólną dla obu grup uzyskano dla 54 haseł (ponad 70\% materiału badawczego), a przynajmniej 1 reakcję odmienną - dla 28 haseł (dla mniej niż $40 \%$ haseł). Reakcje odmienne uzyskano dla przynajmniej jednego hasła z większości klas semantycznych, z wyjątkiem klas: Części ciała, Miejsca handlowo-usługowe, Ludzie, Kosmetyki, Dzieła sztuki i Emocje.

W celu określenia rzeczywistej siły różnic między grupami sprawdzono, czy reakcje dominujące podane tylko przez jedną grupę w ogóle pojawiły się (z innymi rangami) w grupie drugiej, a jeżeli tak, to z jaką częstością. Od osób niewidomych uzyskano 28 reakcji dominujących odmiennych, niż w grupie widzących (są to skojarzenia na 23 hasła). 25 tych reakcji uzyskało w grupie widzących rangi II-V: rangę II uzyskało 10 reakcji, III - 4 reakcje, IV -5 reakcji, V - 5 reakcji. Jedna reakcja pojawiła się $\mathrm{u}$ widzących w randze VIII, jedna jako reakcja indywidualna (podana przez jedną osobę badaną) i jedna nie pojawiła się w ogóle w grupie osób widzących. Te trzy ostatnie reakcje to, odpowiednio: beton - „budowa”, drużyna - ,sport” i sufit - „strop”. Z kolei od osób widzących uzyskano 26 reakcji dominujących odmiennych, niż w grupie niewidomych. $20 \mathrm{z}$ nich pojawiło się w grupie niewidomych na pozycjach II-V: rangę II uzyskało 16 reakcji, III - 3 reakcje, V - 1 reakcja. Dwie reakcje pojawiły się u niewidomych w randze VI, 3 jako reakcje indywidualne, a jedna nie pojawiła się w ogóle w tej grupie osób. Te ostatnie 4 reakcje, to, odpowiednio: autobus - „bilet”(y), ściana - „tapeta”(y), sufit - „lampa”(y) i jaskinia - „niedźwiedź”. 
Siła reakcji dominujących: Siła skojarzeń dominujących, mierzona średnią liczbą osób dających takie skojarzenie, jest nieco wyższa w grupie niewidomych: średnio 30\% niewidomych i 25\% widzących daje skojarzenie dominujące na hasło. Różnica ta, podobnie jak przedstawiony wyżej wskaźnik liczby różnych reakcji na hasło, wskazuje na nieco większą wewnętrzną spójność grupy niewidomych. Zauważono jednak pewne podobieństwa między respondentami niewidomymi a widzącymi w kształtowaniu się siły reakcji dominujących dla poszczególnych haseł stanowiących materiał badawczy: skojarzenia odpowiednio o wysokiej i niskiej sile występują u widzących i niewidomych dla podobnych grup haseł.

Zgodność kategorii gramatycznej między bodźcem a reakcją: Wszystkie reakcje dominujące wspólne dla obu grup należą do tej samej kategorii gramatycznej, co bodziec. Całkowita zgodność kategorii występuje także w przypadku skojarzeń dominujących podanych tylko przez niewidomych: wszystkie są rzeczownikami, przy czym 2 z nich mają charakter odczasownikowy: ślina - „plucie” i krok - „chodzenie” (w podobny sposób można określić także reakcję beton - „budowa”, w znaczeniu „budowanie”). Natomiast wśród reakcji podanych tylko przez grupę widzących jedna należy do innej kategorii gramatycznej, niż bodziec: beton - „twardy”. Wymieniona reakcja przymiotnikowa i reakcje odczasownikowe stanowią skojarzenia o niskiej sile.

Relacje semantyczne: Analizy semantyczne przeprowadzono, kierując się definicjami relacji zawartymi w pracach: Bańczerowski, Pogonowski i Zgółka 1982, Lyons 1984, Miller 1993, Cruse 1986, 2000. Główne kryterium określania relacji między wyrazami stanowiącymi bodźce i reakcje stanowiły definicje tych wyrazów zawarte w słownikach języka polskiego (starano się w ten sposób zminimalizować subiektywizm ocen semantycznych).

Skojarzenia wspólne: Wiele skojarzeń dominujących wspólnych dla obu grup można zakwalifikować jako hiperonimy haseł (wyrazy o szerszym zakresie znaczeniowym, niż zakres hasła). Są to reakcje na następujące hasła (por. tabela): sosna, buk, brzoza, gil, lis, pomidor, marchew, marzec, chata, kamienica, piwo, kietbasa, ciężarówka, symfonia, powieść, posag, metal, morderstwo, wrzask, wzgórze. Jak widać, reakcje o charakterze o szerszym zakresie znaczeniowym niż hasło podawano głównie na hasła z klas: Drzewa, Zwierzęta, Owoce i warzywa, Budynki, Pożywienie, Dzieła sztuki. Jako hiperonim hasła tupot można także potraktować reakcję „,hałas”; dyskusyjność takiej decyzji wynika z relatywnego znaczenia reakcji, utrudniającego dokładne określenie stopnia zbieżności zakresów znaczeniowych obu wyrazów (por. akceptowalne wyrażenie cichy tupot).

Skojarzenia na hasła: radość, zdziwienie, strach, egoista, ręka (por. tabela) oraz odpowiedź „bitwa” na hasło walka można zakwalifikować jako synonimy. Definicje słownikowe pozwalają na potraktowanie w podobny sposób także reakcji ,wojna” na hasło walka (walka - „zorganizowane działanie militarne...w znaczeniu najbardziej ogólnym: wojna”, por. [SJPDun] s. 1204). Za dalszy synonim hasła gang można także uznać reakcję „mafia” w jej najbardziej współczesnym użyciu (por. mafia pruszkowska, wołomińska). Więcej wątpliwości budzi kwalifikacja odpowiedzi biedak„żebrak” oraz lekkomyślność - „głupota”. Pierwszą z nich można potraktować jako daleki synonim hasła albo, bezpieczniej, jako jego hiponim: zastępowanie wyrazu żebrak wyrazem biedak wydaje się akceptowalne w bardziej różnorodnych kontekstach, niż substytucja w przeciwnym kierunku (na temat pokrewieństwa reakcji synonimii i hiponimii por. np. Lyons 1984, Grodziński 1985). Natomiast możliwość użycia wyrazu głupota jako oceny cechy wyrażanej przez rzeczownik lekkomyślność powoduje, że najbardziej obiektywną decyzją wydaje się być potraktowanie relacji między nimi jako kohiponimii.

W przypadku kilku haseł związek między bodźcem a reakcją skojarzeniową można traktować jako relację czesść - całość (relację cząstkowości lub inaczej meronimii). Trzy odpowiedzi stanowią holonimy haseł (tzn. wyrażają one pewną całość, której szeroko rozumianą częścią jest obiekt, stanowiący desygnat hasła): tapa - ,pies”, brygada -,,wojsko” i nauczyciel - ,,szkoła” (szkoła w znaczeniu: „ludzie związani z instytucją oświatową...”, por. [SJPDun] s. 1093). Kolejne trzy reakcje stanowią meronimy haseł, tj. wyrażają część desygnatu hasła lub szeroko rozumiany materiał 
desygnatu: okno - „szyba”, tęcza - „kolor”(y) i rzeka - ,woda” (ostatnią reakcję można także uznać ewentualnie za hiperonim hasła).

W 2 przypadkach odpowiedzi wyrażają cechę (atrybut) desygnatu hasel: dezodorant - „zapach”, jaskinia - „,iemność”, a kolejne 2 reakcje wyrażają bezpośrednio funkcję desygnatu hasła: telefon „rozmowa” i pralka - „pranie”. Pozostałe skojarzenia wspólne dla obu grup na ogół również nawiązują pośrednio do funkcji desygnatu hasła, por. np. oko - „wzrok”, apteka - „leki”, traktor „pole”, boisko -,,piłka”, komin - „dym” itp. Większość z nich można traktować jako rezultat współwystępowania desygnatów bodźca i reakcji w doświadczeniu respondentów (i współwystępowania wyrazów w kontekstach werbalnych).

Skojarzenia otrzymane od grupy niewidomych: 7 z 28 skojarzeń uzyskanych tylko od tej grupy badanych oceniono jako hiperonimy wyrazów hasłowych. Są to reakcje na rzeczowniki: osa, cytryna, wtorek, ser, autobus, gwizd (por. tabela) oraz odpowiedź „wydzielina” na hasło ślina. Odpowiedzi uczciwość - „dobroć” i ostrożność - „uwaga” oraz reakcję „,strop” na hasło sufit można uznać za synonimiczne. Jako dalszy synonim hasła ściana można potraktować odpowiedź „mur”. Natomiast skojarzenie grad - „deszcz” zgodnie z definicjami słownikowymi należy uznać za przypadek kohiponimii. Bardziej dyskusyjne wydaje się zakwalifikowanie odpowiedzi „dach” jako kohiponimu rzeczownika sufit: możliwy wspólny hiperonim musiałby mieć charakter dość rozbudowany (co nie jest zgodne ze ścisłymi językoznawczymi definicjami tej relacji): ?górny ?poziomy element konstrukcji domu.

Skojarzenia uzyskane tylko od niewidomych reprezentują także relację meronimii. Za holonim hasła można uznać reakcję dach - „dom”. Podobnie można potraktować skojarzenia szkto „szklanka”(i) i beton - „,chodnik” (jest to tzw. meronimia materiał - obiekt, por. Miller 1993, Cruse 1986) czy nawet beton - „budowa” (jeśli przyjmujemy znaczenie rzeczownika budowa: „,wznoszony obiekt budowlany...”, por. [SJPDun, s.81). Relacja meronimii odnosi się także do zdarzeń, stąd możliwość zakwalifikowania jako holonimu odpowiedzi „chodzenie” na hasło krok. Więcej zastrzeżeń, płynących z ograniczeń w przechodniości relacji meronimii, budzi potraktowanie jako holonimu reakcji „,dom” na hasło sufit. Z kolei skojarzenia sosna - ,igła”, grad - „lód” i taka „trawa” (taka w znaczeniu: „rośliny rosnące na obszarze...”, por. [SJPDun], s. 481) to meronimy haseł.

Relacja między hasłem pot a reakcją „zmęczenie” ma charakter przyczynowy. Skojarzenie „deszcz” na hasło jesień można traktować jako wyrażenie atrybutu desygnatu hasła. W przypadku pozostałych 4 skojarzeń podanych przez osoby niewidome trudniej jest określić relacje semantyczne między bodźcem a reakcją. Część z nich można potraktować jako związane pośrednio z funkcją desygnatu hasła, np. okno - „widok” czy komputer - ,internet”.

Skojarzenia otrzymane od grupy widzących: Tylko 2 z 26 skojarzeń podanych wyłącznie przez tę grupę można zakwalifikować jako hiperonimy (wtorek - „dzień tygodnia” i drużyna - ,zespół”) i 2 jako synonimy (uczciwość - „szczerośé” i ostrożność - „rozwaga”). Natomiast zakwalifikowanie odpowiedzi „hałas” jako hiperonimu hasła gwizd budzi jeszcze więcej wątpliwości, niż w przypadku hasła tupot (por. wyżej): wyrażenie cichy gwizd wydaje się zupełnie poprawne. Kolejne 2 odpowiedzi należy, zgodnie z definicjami leksykograficznymi, potraktować jako kohiponimy haseł: grad - ,śnieg” i pałac - ,zamek”.

Odpowiedzi szkło - „,szyba”(y) i chata - „wieś" można uważać za przykłady holonimów haseł. Natomiast meronimy haseł stanowią reakcje: osa - „żądło”, dach - „dachówka”(i), cytryna „kwas”, taka - „kwiaty” i kietbasa - „mięso” (kwalifikacja ostatniej reakcji wynika z budowy definicji słownikowych hasła kiełbasa; intuicja wielu użytkowników języka polskiego pozwoliłaby prawdopodobnie na zakwalifikowanie jej jako hiperonimu).

Kilka skojarzeń wyraża atrybut desygnatu gasła: lis - „chytrość”, pot - „smród”, beton „twardy” oraz, ewentualnie, jesień - „liście”.

W przypadku pozostałych 8 skojarzeń uzyskanych tylko od tej grupy osób można mówić jedynie o szeroko rozumianym współwystępowaniu desygnatów hasła i reakcji (i współwystępowaniu w kontekstach werbalnych hasła i reakcji lub wyrazów spokrewnionych z nimi morfologicznie), 
niekiedy powiązanym w jakiś sposób z funkcją jednego z desygnatów, por. np. autobus - „bilet”(y), jaskinia - „,niedźwiedź”, sufit - „lampa”, komputer - „gra”(y), krok - „,noga”(i).

Jak wynika $\mathrm{z}$ powyższych szczegółowych analiz, badani $\mathrm{z}$ obu grup podają skojarzenia powiązane $\mathrm{z}$ hasłami różnymi relacjami semantycznymi. Na uwagę zasługuje duży udział reakcji o zakresie znaczeniowym szerszym, niż zakres bodźca. Od grupy niewidomych reakcje hiperonimiczne uzyskano w sumie dla 27 haseł, a od grupy widzących - dla 22 haseł (pominięto tutaj budząca wątpliwości reakcję „hałas” na hasła tupot i gwizd). Należy także zwrócić uwagę na nikły udział reakcji opozycji w uzyskanych wynikach. Związki tego rodzaju reprezentowane są jedynie przez reakcję kohiponimii (o kohiponimii jako relacji opozycji por. np. Bańczerowski, Pogonowski, Zgółka 1982). Niski udział relacji opozycji jest oczywiście uzasadniony w znacznym stopniu specyfika wykorzystanego materiału badawczego. Jednakże przynajmniej w odniesieniu do rzeczowników z klas: Emocje, Cechy charakteru i Ludzie możliwe jest znalezienie wyrazów pozostających w wyraźnej relacji opozycji (w przypadku wyrazu nauczyciel takim wyrazem mógłby być uczeń, reprezentujący relację konwersji).

Porównanie analiz semantycznych reakcji odmiennych dla obu grup wykazuje nieco silniejszą tendencję do podawania przez osoby niewidome reakcji powiązanych z hasłem związkiem inkluzji, tj. hiperonimów i holonimów haseł (o rodzajach relacji inkluzji por. Kleiber, Tamba 1990).

Nie stwierdzono wyraźnego związku między różnicami w skojarzeniach dominujących podanych przez niewidomych $\mathrm{i}$ widzących a stopniem powiązania haseł $\mathrm{z}$ danymi wzrokowymi. $\mathrm{Na}$ podkreślenie zasługuje fakt uzyskania od obu grup identycznych reakcji (opartych na relacji meronimii) na hasła tęcza i błyskawica.

\subsection{Porównanie treści skojarzeń osób niewidomych i widzących}

Przeanalizowano całe zbiory reakcji uzyskanych na poszczególne hasła pod kątem różnic w treści skojarzeń, które mogą wynikać z odmienności doświadczeń osób widzących i niewidomych.

Zauważono pewne różnice między grupami $\mathrm{w}$ tendencji do podawania reakcji związanych $\mathrm{z}$ kolorem i światłem. W przypadku haseł tęcza i btyskawica, w których kolor i światło stanowia główne cechy budujące znaczenie, reakcje tego typu są u niewidomych nawet częstsze, niż w grupie widzących. W przekazywaniu osobom niewidomych wiedzy na temat takich zjawisk nie można pominąé tych zasadniczych atrybutów i ich wyobrażenia stanowią materiał budujący pojęcia (wyobrażenia zastępcze) tęczy i błyskawicy. Natomiast w przypadkach, gdy kolor lub/i światło są wyraźnymi, ale nie tak centralnymi elementami znaczenia hasła, reakcje związane z takimi cechami pojawiają się nieco częściej u osób widzących. Tendencja ta ujawnia się między innymi w hasłach marchew, lis i piwo, na które więcej niż jeden respondent $\mathrm{z}$ grupy widzących podał skojarzenia związane z kolorem, a w grupie niewidomych takie skojarzenia nie wystąiły w ogóle. Silniejsza skłonność widzących do podawania reakcji tego typu wystąpiła także w przypadku haseł pomidor, ściana, sufit, szkło i dach (różnica między grupami w liczebności takich odpowiedzi wynosi tu przynajmniej 3). Na szczególną uwagę zasługują reakcje na hasło dach: jedyną odpowiedzią niewidomych związaną z kolorem była reakcja „biały”, a więc określenie barwy bardzo nietypowej dla desygnatu hasła (w przeciwieństwie do odpowiedzi „czerwień”, „czerwony” udzielanych przez widzących). Taką reakcję, podobnie jak skojarzenie „białe drzewo” na hasło sosna można traktować jako ujawniającą brak dostępności desygnatu przymiotnika biaty dla niewidomego respondenta (wymienione dwie odpowiedzi podane zostały przez dwie różne osoby badane) ${ }^{4}$.

Sprawdzono również, czy w skojarzeniach podawanych przez osoby niewidome można odnaleźć przejawy kompensacji zmysłowej, polegające na podawaniu odpowiedzi związanych z percepcja słuchowa, dotykowa itp. Porównanie reakcji obu grup pod tym względem ukazuje tendencje stanowiące w pewnym stopniu zwierciadlane odbicie opisanych powyżej różnic dotyczących koloru i

\footnotetext{
${ }^{4}$ Żadnej odpowiedzi udzielonej w teście skojarzeń swobodnych nie można, oczywiście, uznać za niepoprawną. Ponadto zarówno sosna, jak i dach w pewnych warunkach stają się białe, np. pokryte śniegiem lub szronem i konteksty werbalne opisujące takie sytuacje mogą wpłynąć na skojarzenia podawane podczas badania.
} 
jasności. Jednym z najważniejszych dla człowieka atrybutów desygnatu rzeczownika cytryna jest kwaśny smak. Reakcje związane z tą cechą pojawiają się często u respondentów obu grup, a nawet częściej u osób widzących (w tej grupie jedna $\mathrm{z}$ takich reakcji jest skojarzeniem dominującym, podczas gdy u osób niewidomych reakcją najczęstszą jest hiperonim „owoc”, por. tabela). Podobna, choć nieco słabsza tendencja w reakcjach obu grup występuje w przypadku hasła beton i odpowiedzi związanych z cechą twardości (rola tej cechy jest dominująca ze względu na funkcję betonu jako materiału budowlanego). Różnicę o przeciwnym biegunie znajdujemy w odpowiedziach na hasło szkło: wyraźne, ale być może nie tak dominujące w doświadczeniu osób widzących atrybuty kruchości, delikatności i gładkości przejawiają się częściej w reakcjach respondentów niewidomych. Ten sam kierunek różnicy widoczny jest w skojarzeniach na hasła ciężarówka oraz błyskawica: reakcje związane z głośnym dźwiękiem desygnatu hasła są nieco częstsze u niewidomych. Ponadto są hasła, w przypadku których przynajmniej jeden respondent niewidomy podał odpowiedź związaną ze zmysłem słuchu, dotyku, smaku, węchu (np. krok - „stuk”, marchew - „chrupanie”, ściana „,szorstka”, podłoga - „,kkrzyp”, nauczyciel - „gruby głos”), a żaden respondent widzący nie podał takiej reakcji. Sytuacja przeciwna - reakcje tego typu podawane wyłącznie przez respondentów widzących -wystepuje rzadziej.

Niektóre skojarzenia podawane przez respondentów mają charakter emocjonalno-oceniajacy: nazwy stanów emocjonalnych oraz zjawisk i zdarzeń wywołujących wyraźne emocje, a także przymiotniki i rzeczowniki wartościujące itp. Reakcje tego typu są niekiedy powiązane w sposób oczywisty ze znaczeniem hasła, np. hasło krew prowadzi do skojarzeń wskazujących sytuacje, w których występuje desygnat hasła (np. „śmierć”, „morderstwo”), a hasło wrzask wywołuje reakcje określające przyczynę wrzasku (np. „złość”, „strach”, „,zabijanie”). W innych przypadkach odpowiedzi można traktować jako ocenę desygnatu hasła, np. nauczyciel - „egoizm”, „cierpliwość”, symfonia - „piękno”, „nuda” itp. Jako reakcje tego rodzaju można także traktować skojarzenia ściana - „przeszkoda”. Analiza wszystkich uzyskanych wyników nie wykazuje znaczących różnic między grupami w ogólnej sile tendencji do podawania reakcji emocjonalno-oceniających. Jako przykład wyrównywania się tej tendencji można przytoczyć reakcje na hasła morderstwo i walka: skojarzenia typu „okrucieństwo”, „zło”, „katastrofa”, „grzech”, „tragedia” itp. na morderstwo są nieco częstsze u niewidomych, a widzący udzielają nieco częściej odpowiedzi typu „,przemoc”, „,śmierć”, „,ból”, „,złość” itp. na hasło walka. Zwrócono jednak uwagę na różnice dotyczące kilku haseł. Na hasło nauczyciel 14 osób widzących udzieliło odpowiedzi omawianego rodzaju, z czego znaczną większość (11) stanowiły oceny negatywne (np. „zło”, „egoizm”, „gniewność”[gniew], „sadysta”, „wróg” itp.), podczas gdy skojarzenia tylko 6 osób niewidomych miały charakter emocjonalno-oceniający, z czego 4 można uznać za negatywne (reakcje „gadatliwość”, „nuda” oraz dwukrotnie podana odpowiedź „stres”). Bardziej oceniający charakter mają także odpowiedzi widzących na hasło powiesśc. Hasło komputer wzbudziło emocje zaledwie u kilku respondentów, ale są to uczucia i oceny odmienne u niewidomych (,durny”, „udręka”, „bezduszność”) i widzących (,przyjemność”, ,zabawa”). Dane z tabeli wskazują zresztă, że uczniowie widzący znacznie częściej wykorzystują komputer jako narzędzie rozrywki (dominującą w tej grupie reakcję „gra”(y) podało prawie 30\% respondentów). Kolejna różnica dotyczy haseł z klasy Czesści domu: dach i okno tylko u osób widzących wywołują skojarzenia typu „samobójca”, „samobójstwo”, ,skok z 7 piętra”. Natomiast niewidomi częściej podają reakcje typu „przeszkoda”, „,blokada” na hasło ściana. Ponadto tylko osoby niewidome podają skojarzenia emocjonalne („,radośé”, „obawa”) na hasło oko.

Skojarzenia podane przez osoby niewidome i widzące dość wyraźnie różnią się siłą odniesienia do otaczającej rzeczywistości, kultury i sztuki. Reakcje tego rodzaju pojawiają się szczególnie w odpowiedzi na hasła z klas: Dzieła sztuki (nazwy obiektów wyobrażanych przez posagi, np. „Zeus”, „Atena”, „Mickiewicz”, „Budda”, „Sfinks” itp.; autorzy i tytuły powieści, np. „Sienkiewicz”, „Tolkien”, „W pustyni i w puszczy”, „Mistrz i Małgorzata”, „Władca Pierścieni” itp.), Grupy ludzi (reakcje filmowo-literackie: drużyna - „Władca Pierścienia”, „pierścień”, „,film”; gang - „Olsena”, „film”; brygada - „pierścień”, „,bajka”, „Chip i Daile”, „Pokemon” itp.; odpowiedzi związane z polityką i gospodarką: gang - „Bin Laden”, ,syndykat”; ze sportem: drużyna - „Lech Poznań”, „Lech”; z muzyką: brygada - „Akapulko”), Elementy krajobrazu 
(reakcje filmowo-literackie: wzgórze - „Bilbo, „Ania /z Zielonego Wzgórza/”, „Wichrowe”; rzeka „film”, „Kwai” itp.; nazwy geograficzne: rzeka - „Warta”, „Wisła”, „Tamiza”, „Nil”, „rzeka Odra”, itp.), Budynki (odpowiedzi baśniowo-filmowo-literackie: chata - „Baba Jaga”, „Wuja Toma”; pałac - „elfy”, „Morii”, „smok”, „bajka”; nazwy geograficzne: pałac - „Wieden””, „Lubostroń”; nazwy własne budynków: pałac - „Zimowy”, „Kultury”, „Buckingham”; reakcje o charakterze historycznym lub baśniowo-literackim: pałac - „Krzyżacy”, „król”, „książę”, „,car”, „cesarz” itp.), Urządzenia (reakcje filmowo-literackie telefon - „Matrix”, komputer - „Mugol” i nazwy urządzeń typu pralka - „Frania”, „Whirpool”; komputer - „Word”, „Linux”), Pożywienie (głównie nazwy produktów i miejsc produkcji, np. piwo - „Winthrop”, „Bierstein”, „Lech”, „Żywiec”; ser - „Szwajcarek”, „Podlaski”, „Francja”, „Szwajcaria”). Zarówno w przypadku rzeczowników z wymienionych klas, jak i w przypadku innych haseł więcej skojarzeń omawianego typu pochodzi z wyników uzyskanych od respondentów widzących. Szczególnie duże różnice dotyczą odpowiedzi ,filmowych”. (W odpowiedziach uczniów widzących pojawia się sporo skojarzeń wywołanych prawdopodobnie emisją pierwszej części trylogii „Władca Pierścieni” w okresie przeprowadzania badań. Np. obok reakcji wymienionych powyżej 3 osoby udzieliły odpowiedzi oko - „Sauron”). Osoby widzące podają jednak także znacząco więcej reakcji związanych z różnymi aspektami współczesnego życia (np. lis - „Tomasz Lis”, uczciwość - „Matka Teresa z Kalkuty”, podtoga - „Cif”, „Ajax”, ściana - „płaczu”, „Żydzi” itp.). Odwrotną tendencję - nieco większą liczbę reakcji omawianego typu w grupie niewidomych - można dostrzec właściwie jedynie w przypadku hasła walka (tylko w tej grupie pojawiły się skojarzenia ponadindywidualne „rycerze” i „Afganistan”).

Wyraźne różnice $\mathrm{w}$ treści skojarzeń wystąpiły w przypadku hasła oko: występujące u osób widzących reakcje kulturowe (,Sauron”, „Big Brother”) zostały w grupie niewidomych zastapione przez reakcje emocjonalne (,radość”, „obawa”) oraz związane z dysfunkcją wzroku (,ślepota”, „nie widzieć”, ,astygmatyzm”, ,jaskra”).

\section{Podsumowanie}

Przeprowadzone analizy ukazują silne podobieństwo skojarzeń podawanych przez niewidomych i widzących użytkowników języka polskiego, przejawiające się w:

- $\quad$ wysokiej liczbie skojarzeń najczęstszych (dominujących) wspólnych dla obu grup,

- pojawianiem się prawie wszystkich reakcji dominujących dla jednej grupy jako reakcji o wysokiej randze także w drugiej z grup,

- bardzo silnej zgodności kategorii gramatycznej między bodźcami a reakcjami dominującymi w wynikach obu grup,

- tendencji do podawania skojarzeń stanowiących hiperonimy bodźców, ujawnionej w odpowiedziach najczęstszych podawanych zarówno przez niewidomych, jak i widzących,

- braku wyraźnego wpływu związku danych wzrokowych ze znaczeniem hasła na różnice między skojarzeniami dominującymi niewidomych i widzących,

- podobnej ,temperatury emocjonalnej” reakcji podawanych przez obie grupy osób.

Uzyskana w obecnych badaniach zgodność skojarzeń dominujących dwóch grup użytkowników języka polskiego jest wyższa, niż w przypadku skojarzeń podawanych przez użytkowników różnych języków naturalnych (por. Kurcz 1967 oraz Rosenzweig 1957, 1961, Russell i Meseck 1959, za: Kurcz 1976). Zgodność skojarzeń między polskimi respondentami niewidomymi a widzącymi, dotycząca ponad $70 \%$ materiału badawczego, jest także wyższa, niż zgodność skojarzeń dominujących uzyskanych od użytkowników języka polskiego w latach 60-tych i w latach 90-tych dwudziestego wieku w badaniach testem Kent-Rosanoffa: zgodność między wynikami uzyskanymi od tych dwóch grup widzących respondentów należących do różnych pokoleń wynosi około $50 \%$ 
(Łobacz, Mikołajczak-Matyja 2002) $)^{5}$. Skojarzenia osób niewidomych i widzących osiagają prawie tak wysoki stopień zgodności, jak skojarzenia badanych równocześnie dwóch grup osób widzących o tym samym wykształceniu i posługujących się tym samym językiem: zgodność taka w przypadku studentów i studentek polskich dotyczyła 77\% bodźców, a w przypadku francuskich - 75\% bodźców (za: Kurcz 1976).

Ujawniona w obecnym badaniu tendencja do podawania rzeczowników w odpowiedzi na bodziec rzeczownikowy wydaje się być powszechna w przypadku użytkowników języka polskiego: w polskich normach skojarzeniowych z lat 90-tych dla 69 rzeczowników z listy Kent-Rosanoffa uzyskano 64 reakcje dominujące stanowiące rzeczowniki (Łobacz, Mikołajczak-Matyja 2002).

Wysokie podobieństwo skojarzeń werbalnych podawanych przez osoby niewidome i widzące posługujące się tym samym językiem nie jest specyficzne jedynie dla społeczności języka polskiego (por. np. Elbers, van Loon-Vervoorn 1999). Takie podobieństwo stanowi niewątpliwy dowód silnej niezależności procesów językowych od percepcji wzrokowej. Natomiast interpretacje wszelkich różnic zarysowujących się w wynikach badanych niewidomych i widzących mogą mieć charakter jedynie hipotez, dotyczących wpływu zmysłu wzroku na procesy językowe i pozajęzykowe przejawiające się w skojarzeniach. Przeprowadzone analizy odsłoniły następujące różnice w odpowiedziach grupy eksperymentalnej i kontrolnej:

- Odpowiedzi grupy eksperymentalnej są mniej zróżnicowane. Wyższą wewnętrzną spójność wyników respondentów niewidomych (wyrażającą się w większej liczbie reakcji na hasło i w wyższej sile reakcji dominujących) można traktować jako wynik mniejszego zróżnicowania informacji o świecie docierających do osób o uszkodzonym narządzie wzroku i przebywających głównie w ośrodkach szkolno-wychowawczych.

- Jako hiperonimy i holonimy haseł zaklasyfikowano większą liczbę reakcji dominujących uzyskanych od osób niewidomych, niż od widzących. Rezultat ten można interpretować jako nieco silniejszą tendencję niewidomych do przejawiania w skojarzeniach sposobu porządkowania rzeczywistości, wynikającą z odmienności sposobu uzyskiwania informacji o świecie i kompensacyjnej roli języka w tym procesie: niewidomi uzyskują wiele danych poprzez zwerbalizowane wyjaśnienia o charakterze definicyjnym, porządkującym. Stąd u niewidomych dominująca reakcja autobus - ,pojazd” zamiast „,bilet”(y) czy ser - ,jedzenie” zamiast „mysz" itd. W taki sam sposób można wyjaśniać np. zastępowanie przez niewidomych reakcji sufit - „lampa” i ściana - „tapeta” reakcjami synonimicznymi, odpowiednio „strop” i „mur”. Różnicę w tendencji do podawania hiperonimów można także wiązać z odmiennością funkcjonowania procesów abstrahowania i uogólniania u niewidomych, podkreślaną w literaturze tyflopsychologicznej (np. Sękowska 1974, Klimasiński 1989, Warren 1994).

- Nasilenie skojarzeń związanych z różnymi rodzajami percepcji jest odmienne w obu grupach, co skłania do formułowania hipotez dotyczących struktury pojęć. Cechy zmysłowe inne niż wzrokowe wydają się odgrywać nieco większą rolę w strukturze pojęć niewidomych, niż widzących (np. w pojęciu szkła, ciężarówki itd.), nie dotyczy to jednak bardzo silnych, dominujących cech desygnatów pojęć (jak twardość betonu czy kwaśny smak cytryny). Z kolei cechy wzrokowe odgrywają większą rolę w strukturze pojęć tworzonych przez osoby widzące (np. w pojęciach marchwi, piwa, lisa itp.). Natomiast w przypadku bardzo silnych, dominujących cech wzrokowych desygnatów pojęcia (jak w przypadku tęczy czy błyskawicy) konstrukcja pojęcia u niewidomych opiera się na wyobrażeniach zastępczych tych cech, uzyskanych w procesie analogii.

\footnotetext{
${ }^{5}$ Należy jednak pamiętać, że grupy badane w latach 60-tych i 90-tych różniły się także wiekiem w momencie badania oraz wykształceniem: grupę respondentów z badania wcześniejszego stanowią studenci, a grupę badaną później uczniowie różnych szkół średnich. Różnice te mogły obniżyć zgodność wyników uzyskanych od obu grup (por. Łobacz, Mikołajczak-Matyja 2002).
} 
- Niektóre elementy rzeczywistości wywołują u niewidomych emocje o innym natężeniu lub nawet znaku, niż u osób widzących: np. komputer nie jest dla niewidomych tak częstym źródłem przyjemności i rozrywki, a nauczyciel nie wywołuje tak silnych emocji negatywnych.

- Przenikanie kultury i różnych zjawisk życia codziennego do środowiska młodzieży niewidomej jest słabsze, niż w przypadku osób widzących.

Powyższe hipotezy mogą zostać zweryfikowane w kolejnych eksperymentach psychologicznych i psycholingwistycznych. Zatem można powiedzieć, że zastosowanie eksperymentu skojarzeniowego do badań porównawczych nad osobami niewidomymi umożliwia zarówno określenie stopnia niezależności procesów językowych od percepcji wzrokowej, a więc od procesów pozajęzykowych, jak i formułowanie hipotez wyznaczających kierunki dalszych badań nad funkcjonowaniem językowym i pozajęzykowym osób niewidomych.

\section{Literatura cytowana}

Bańczerowski, J., Pogonowski, J., Zgółka, T. 1982. Wstęp do językoznawstwa. Poznań: UAM.

Bock, J. K. 2002. Meaning, sound, and syntax. Lexical priming in sentence production. W: G.T.M. Altmann (red.). Psycholinguistics. Critical concepts in psychology. T.V. Londyn, Nowy Jork: Routledge, ss. 378-404.

Ciechanowicz, A. 1975. Swobodne skojarzenia słowne. Przegląd literatury. Psychologia Wychowawcza 4/1975. ss. 520-534.

Cieślicka-Ratajczak, A. 1995. The mental lexicon in second language learning. Studia Anglica Posnaniensia 29. ss. 105-117.

Cronin, V.S. 2002. The syntagmatic-paradigmatic shift and reading development. Journal of Child Language 29. 1, ss. 189-204.

Crowe, K.M., Kroll, R.M. 1991. Response latency and response class for stutterers and nonstutterers as measured by a word-assciation task. Journal of Fluency Disorders 16, 1. ss. $35-54$.

Cruse, D.A. 1986. Lexical semantics. Cambridge: Cambridge University Press.

Cruse, D.A. 2000. Meaning in language. An introduction to semantics and pragmatics. Oxford: University Press.

Deese, J. 1965. The structure of associations in language and thought. Baltimore: John Hopkins Press.

Elbers, L., Van Loon-Vervoorn, A. 1999. Lexical relationships in children who are blind. Journal of Visual Impairment and Blindness 93, 7. ss. 419-421.

Ferrand, L. 2001. Normes d'associations verbales pour 260 mots „abstraits”, L'Année Psychologique 101, 4. ss. 683-721.

Ferrand, L., Alario, F.-X. 1998. Normes d'associations verbales pour 366 noms d'objets concrets. L'Année Psychologique 98, 4. ss. 659-709.

Forster, K.I. 2002. Accessing the mental lexicon. W: G.T.M. Altmann (red.). Psycholinguistics. Critical concepts in psychology. T.I. Londyn, Nowy Jork: Routledge. ss. 270-296.

Grodziński, E. 1985. Językoznawcy i logicy o synonimach i synonimii. Wrocław: Ossolineum.

Harley, T. 2003. The psychology of language. Hove, Nowy Jork: Psychology Press.

Hirsh, K.W., Tree, J.J. 2001. Word sssociation norms for two cohorts of british adults. Journal of Neurolinguistics 14,1 . ss. 1-44.

Hörmann, H. 1972. Introduction à la psycholinguistique. Paris: Librairie Larousse.

Houde, O. 1990. Logical categorization: schematic knowledge, categorical knowledge, and image versus linguistic format. A study in six- to eleven-year-olds. Cahiers de Psychologie Cognitive 10, 4. ss. 343-384.

Hunca-Bednarska, A.1997. Skojarzenia werbalne w schizofrenii. Lublin: Czelej.

Jenkins, J.J. 1960. Commonality of association as an indicator of more general patterns of verbal behaviour. W: T.A. Sebeok (red.). Style in language. New York: J. Wiley. ss. 307-329. 
Johnson, D.E., Shean, G.D. 1993. Word associations and schizophrenic symptoms. Journal of Psychiatric Research 27, 1. ss. 69-77.

Kleiber, G., Tamba, I. 1990. L'hyponymie revisitée: inclusions et hiérarchie. Langages 98. ss. 7-32.

Klimasiński, K. 1989. Organizacja czynności poznawczych przy głębokim defekcie wzroku. Kraków: UJ.

Kurcz, I. 1967. Porównania powszechności skojarzeń w różnojęzycznych grupach studenckich. Studia Psychologiczne VIII. ss. 256-271.

Kurcz, I. 1976. Psycholingwistyka. Warszawa: PWN.

Kurcz, I. 2000. Psychologia języka i komunikacji. Warszawa: Scholar.

Latour, M.A., McKelvie, S.J. 1994. Effects of type of input and type of processing on recall hypermnesia. Revue canadienne de psychologie experimentale 48, 3. ss. 451-459.

Lyons, J. 1984. Semantyka. Warszawa: PWN.

Łobacz, P., Mikołajczak-Matyja, N. 2002. Skojarzenia stowne w psycholeksykologii i onomastyce psycholingwistycznej. Poznań: Sorus.

Majewski, T. 1983. Psychologia niewidomych i niedowidzacych. Warszawa: PWN.

Miller, G.A. 1993. Nouns in WordNet: a lexical inheritance system. Princeton.

Moss, H.E., McCormick, S.F., Tyler L.K. 2002. The time course of activation of semantic information during spoken word recognition. W: G.T.M. Altmann (red.). Psycholinguistics. Critical concepts in psychology. T.II. Londyn, Nowy Jork: Routledge. ss. 84-119.

Moss, H.E., Ostrin, R.K.., Tyler, L.K., Marslen-Wilson, W.D. 1995. Accessing different types of lexical semantic information: evidence from priming. Journal of Experimental Psychology: Learning, Memory, and Cognition 21, 4. ss. 863-883.

Niesiołowska, U. 1985. Sprawność w poruszaniu się niewidomych a czynniki emocjonalne. Przegląd Tyflologiczny 14/15. ss. 40-52.

Pérez-Pereira, M., Conti-Ramsden G. 1999. Language development and social interaction in blind children. Hove (UK): Psychology Press.

Pietrulewicz, B. 1981. Przystosowanie poznawcze niewidomych. Przeglad Tyflologiczny 6/7. ss. 7073.

Pietrulewicz, B. 1983. Rozwój rozumowania przez analogię $u$ dzieci niewidomych $w$ wieku szkolnym. Monografie psychologiczne t. XVI. Wrocław: Ossolineum.

Rommetveit, R. 1968. Words, meanings and messages. Theory and experiments in psycholinguistics. Londyn, Nowy Jork: Academic Press.

Sękowska, Z. 1974. Ksztatcenie dzieci niewidomych. Warszawa: PWN.

Shugar, G. Gepner-Więcko, K. 1970. Porównanie skojarzeń z punktu widzenia różnic formalnych w strukturze języka polskiego i angielskiego. Psychologia Wychowawcza T. XIII/4. ss. 513-522.

Simpson, G.B. Lexical ambiguity and its role in models of word recognition. W: G.T.M. Altmann (red.). Psycholinguistics. Critical concepts in psychology. T.II. Londyn, Nowy Jork: Routledge. ss. 140-176.

[SJPDun]: Dunaj, B. (red.). 1996. Stownik wspótczesnego języka polskiego, Warszawa: Wilga.

Szczechowicz, A. 1976. Swoistość kształtowania się pojęć u dzieci niewidomych. W: K. Klimasińnki (red.). Procesy poznawcze a defekty sensoryczne, Materiaty I Krajowego Sympozjum Psychologii Defektologicznej. Warszawa: PZG, PZN, UJ Instytut Psychologii. ss. 86-99.

Tomaszewski, T. 1986. Gtówne idee wspótczesnej psychologii. Warszawa: Wiedza Powszechna.

Upmanyu, V.V., Bhardwaj, S., Singh, S. 1996. Word-association emotional indicators: associations with anxiety, psychoticism, neuroticism, extraversion, and creativity. The Journal of Social Psychology 136, 4. ss. 521-529.

Warren, D.H. 1994. Blindness and children. Nowy Jork: Cambridge University Press.

Wilks, C., Meara, P. 2002. Untangling word webs: graph theory and the notion of density in second language word association networks. Second Language Research 18, 4. ss. 303-324.

Wolter, B. 2002. Assessing proficiency through word associations: is there still hope? System 3, 3. ss. 315-329. 


\section{Summary}

The history of verbal association experiments indicates a possibility of interpreting their results both in terms of the language behaviour characteristics of the studied persons, and in terms of nonlanguage processes which are an area of interest of psychology. The role of such experiments in contemporary science is confirmed by studies carried out over the past dozen or so years. Association experiments and re-developed association norms are used extensively in research into the language processing, acquisition of a second language, memory, cognitive development of children, personality, etc.

The main objective of the present paper consisted in determining the role of visual perception in the cognitive functioning of people through a detailed comparative analysis of verbal associations given by blind and sighted users of the Polish language. 58 blind (completely blind or only with a minimal light perception) and 58 sighted secondary school students were asked to give the first word associated with every word-stimulus included in a list of 75 Polish nouns belonging to various lexical fields. The numeric and content analyses of their reactions indicate a strong similarity of the associations given by both groups, as demonstrated in:

- a high number of the most frequent (dominant) associations common to both groups,

- the appearance of almost all dominant reactions in one group as high-ranking reactions in the other group,

- the tendency to give associations which are hyperonyms of stimuli, shown in the most frequent responses of both groups,

- the lack of a clear impact of the connection between visual data and the meaning of the stimulus upon the differences between the dominant associations of the sighted and unsighted persons.

The aforementioned similarities provide clear evidence of considerable independence of language processes and visual perception. However, the analyses carried out also uncovered differences in the responses given by sighted and blind persons, enabling the following hypotheses to be put forward as regards the impact of sight upon language and non-language processes:

- The information on the world reaching unsighted young people (living mainly in education establishments) is less varied that in the case of their sighted peers, as evidenced by a greater diversification of association reactions in the latter group. Moreover, the differences in the method of acquiring information and the compensatory role of the language in that process result in a slightly stronger tendency of the unsighted respondents to show a method of systematising reality in their associations (by giving associations that were hyperonyms and holonyms of the stimuli).

- Different structure of concepts: Sensuous traits other than the visual ones seem to play a slightly greater role in the structure of concepts of unsighted people, than is the case with people with unimpaired eyesight. However, this does not apply to very strong, dominating traits of objects (such as the hardness of concrete or the acidic taste of lemons). Meanwhile, visual characteristics play a more pronounced role in the structure of many concepts created by sighted people (e.g. the concept of carrot, fox, beer, etc.). When it comes to very strong, dominant visual characteristics of the concept designation (for instance, characteristics of a rainbow or a lightning) the structure of the concept among unsighted people is based on "ersatz representations" of these characteristics obtained by way of analogy.

- The penetration of culture and various everyday life phenomena into the community of blind youths is weaker than in the case of sighted persons.

The hypotheses may be verified in the course of follow-up psychological and psycholinguistic research. 